\title{
STOCKHOLDER CONSENT TO SALES OF INTEGRAL CORPORATE ASSETS: BALANCING DISSENTER AND PURCHASER INTERESTS*
}

SALE by a corporation of substantially all or an integral part of its assets often engenders conflicts among shareholders and between them and the purchaser. ${ }^{1}$ At common law, such sales generally necessitated unanimous shareholder approval $^{2}$ on the theory that each stockholder had a right to protect his interest

\footnotetext{
*Eisen v. Post, 3 N.Y.2d 518, 146 N.E.2d 779 (1957), reversing 1 App. Div. 2d 344, 149 N.Y.S.2d 864 (1st Dep't 1956).

1. This Note is primarily concerned with the sale, lease or exchange of all assets by a corporation intending to continue in business without changing the corporate form and without distributing the proceeds to shareholders. Sales or exchanges made pursuant to a corporate merger, consolidation or dissolution are not discussed. Statutes commonly provide different procedures and stockholder rights for each of these transactions. See, e.g., N.Y. STOCK CoRp. Law $\$ \S 20$ (sale of assets), 85 (merger with subsidiary), 86 and 91 (merger and consolidation), 105 (dissolution); DEL. CODE ANN. tit. 8, \$\$ 271 (sale of assets), 253 (merger with subsidiary), 251 and 252 (merger and consolidation), 275 (dissolution) (Supp. 1956). A sale of assets does not constitute a dissolution requiring liquidation of the corporation unless so labeled. See Geiger v. American Seeding Mach. Co., 124 Ohio St. 222, 177 N.E. 594 (1931) ; see also Opelka v. Quincy Memorial Bridge Co., 335 I11. App. 402, 82 N.E.2d 184 (1948). In some states, sale-of-asset statutes apply to the authorization of a mortgage covering all or substantially all of a corporation's assets. See Ilt. Ann. Stat. c. 32, § 157.72 (Smith-Hurd 1957). See also McDonald v. First Nat'1 Bank, 70 F.2d 69 (1st Cir. 1934) ; Commerce Trust Co. v. Chandler, 284 Fed. 737 (1st Cir. 1922) ; Greene v. RFC, 24 F. Supp. 181 (D. Mass. 1938) (dictum) ; cf. Greene v. RFC, 100 F.2d 34 (1st Cir. 1938). But see Cal. Corp. Code $§ 3900$; OHro Rev. Code AnN. $\S 1701.65$ (Page Supp. 1957) (no stockholder authorization for mortgage required unless corporate charter otherwise provides). See also Note, 51 HaRv. L. REv. 1074 (1938). Cf. N.Y. STOCK CoRp. LAw $\$ \S 16,17$ (separate statutory provision on corporate mortgages).

2. Geddes v. Anaconda Copper Mining Co., 254 U.S. 590 (1921) ; People v. Ballard, 134 N.Y. 269, 32 N.E. 54 (1892) ; Ballantine, Corporations $\$ 281$, at $666 \mathrm{n} .13$ (rev. ed. 1946) (collecting cases) (hereinafter cited as Ballantine). See Notes, 46 Calif. L. Rev. 283, 284 (1958), 94 U. PA. L. Rev. 412 (1946); see also 46 CoLuMr. L. Rev. 1020, 1021 (1946).

The common law relaxed the requirement of stockholder approval when the corporation was insolvent or in danger of failure. Geddes v. Anaconda Copper Mining Co., supra; Skinner v. Smith, 134 N.Y. 240, 31 N.E. 911 (1892) ; Holmes \& Griggs Mfg. Co. v. Holmes \& Wessel Metal Co., 127 N.Y. 252, 27 N.E. 831 (1891); 18 C.J.S., Corporations $\$$ 515, at $1195 \mathrm{n} .97$ (1939) (collecting cases). Authority is divided on the effect of statutory provisions on the common-law "failing corporation exception." See 6A FLETCHER, PRIVATE Corporations $\$ 2949$ (perm. ed. rev. repl. 1950) ; Comment, 45 Mrch. L. Rev. 341, 346-4\$ (1947). For the New York view, compare In the Matter of MacDonald, 205 App. Div. 579, 199 N.Y. Supp. 873 (2d Dep't 1923) (dictum that sale by insolvent corporation requires compliance with the statutory procedure), with In the Matter of Avard, 5 Misc. 2d 817, 144 N.Y.S.2d 204 (Sup. Ct. 1955), appeal dismissed, 2 App. Div. 2d 647, 156 N.Y.S.2d 970 (4th Dep't 1956) (sale by insolvent corporation held outside the statute). See also Michigan Wolverine Student Co-Operative, Inc. v. Wm. Goodyear \& Co., 314 Mich. 590, 22 N.W.2d 884 (1946) (dictum refusing to read failing corporation exception into the Michigan statute).
} 
in assets essential to the corporation's chartered purpose. ${ }^{3}$ Since ability to veto a potentially advantageous sale or to set aside a bona fide purchase enabled the dissenting stockholder to demand an exorbitant price for his concurrence, ${ }^{4}$ forty-five states passed laws reducing to a specified majority the percentage of shares whose owners must endorse a legal sale of key assets. ${ }^{5}$ Twenty-six of these states afford a dissenter some protection by allowing him, on timely demand, to have his stock judicially appraised and purchased by the corporation. ${ }^{6}$

The applicability of most shareholder-consent statutes is limited expressly or through construction to sales outside the regular course of corporate business. ${ }^{7}$ This qualification is designed to facilitate transfers by companies whose

3. See In the Matter of Timmis, 200 N.Y. 177, 181, 93 N.E. 522, 523 (1910) ; BALLANTINE $\$ 281$. See also Note, 58 Colun. L. Rev. 251, 251-52 (1958).

4. See Voeller v. Neilston Co., 311 U.S. 531, 535 n.6 (1941) ; In the Matter of Timmis, supra note $3 ; 3$ WhIte, New YoRK CoRporations $\$ 20$ (12th ed. 1947).

5. See Parker, Corporation Manual $\$ 45$ (all states) (59th ed. 1958) (listing statutes); Note, 58 Coluar. L. Rev. 251, 253 (1958); see also Ballanmine $\$ 282$.

6. Authorities cited note 5 supra. See, e.g., Ill. Ann. Stat. c. 32, $\$ 157.73$ (SmithHurd 1957) ; N.J. Stat. ANn. \$ 14:3-5 (Supp. 1957); N.Y. Stock CoRp. LaW \$ 20; OHIo Rev. Code Ann. \& 1701.76 (Page Supp. 1957).

Forty-three jurisdictions have statutes granting stockholder appraisal rights in the event of one or more types of voluntary corporate readjustment. Of these, forty-two grant appraisal to dissenters from mergers or consolidations, twenty-six to dissenters from asset sales, and thirteen to dissenters from certain charter amendments. Note, 60 YALE L.J. 336, 339 n.7 (1951). This piecemeal scope of appraisal statutes has been severely criticized. Since different readjustment devices often attain the same result, management can sometimes avoid payment to dissenters by simply choosing a device under which the statute does not give appraisal rights. See Hills, Consolidation of Corporations by Sale of Assets and Distribution of Shares, 19 CALIF. L. REv. 349 (1931) ; Weiner, Payment of Dissenting Shareholders, 27 CoLUM. L. REv. 547, 564 (1927). New York, however, provides stockholders with an extensive arsenal of appraisal rights, permitting a dissenter to get appraisal of his shares upon sale of assets, alteration of preferential rights by charter amendment, merger or consolidation, institution of certain employee stock pension plans, and voluntary dissolution. N.Y. STock CoRP. LAW $\$ \$ 20,38,85,86,91,105$.

Under some statutes, holders of preferred stock are not given voting rights on asset sales. See Ballantine 669. Appraisal statutes generally, however, do not restrict the right to vote on asset sales and allow appraisal to any class of stockholder. Note, 60 YALE L.J. 336, 338 n.5 (1951). In New York, holders of nonvoting stock have neither right. In the Matter of Harwitz, 192 Misc. 91, 93, 80 N.Y.S.2d 570, 573 (Sup. Ct. 1948) (interpreting "entitled to vote thereon" language in $\$ 20$ of N.Y. STock CoRP. LAW). For criticism of this holding, see Note, 60 Yale L.J. 336, 338 n.5 (1951). For general treatment of appraisal statutes, see Ballantine $\$ \S 298,299$; Strvens, Corporations $\$ 128$ (2d ed. 1949); Notes, 28 N.Y.U.L. REv. 1021 (1953), 38 VA. L. Rev. 915 (1952).

7. See Ill. Ann. Stat. c. 32, \$157.72 (Smith-Hurd 1957); ME. Rev. Stat. Ann. c. 53, § 84 (Supp. 1957) ; PA. Stat. Ann. tit. 15, § 2852-31.1 (Supp. 1957) ; S.C. Code ANN. $\$ 12-631$ (Supp. 1955). N.Y. Stock CoRp. LaW $\$ 20$, quoted in full note 12 infra, was amended in 1954 to exclude transactions in the regular course of business. The Association of the Bar of the City of New York reported on the amendment: "This change is in substantial accord with the judicial interpretations of the existing statute and would bring Section 20 in line with the provisions of similar statutes in other states." THE Assocta- 
stock in trade consists of capital assets. Thus, a corporation organized for and continually engaged in the conveyance of realty need not obtain stockholder approval for each transaction. ${ }^{8}$ Where, however, a company selling its real property may do so under its charter but has in the past been exclusively engaged in some other business, the pertinence of stockholder-consent legislation is uncertain. ${ }^{9}$ Moreover, if the sale, falling without the normal scope of busi-

tion of the Bar of the City of New York, Committee on State Legislation, Report No. 78 (1953). The Wisconsin statute specifically exempts corporations organized for the purpose of trading in property. Wrs. Stat. Ans. $\$ 180.70(3)$ (1955). See Comment, 45 Mrch. L. Rev. 341, 348 n.32 (1947) ; see also 1947 Wrs. L. Rev. 396.

In judicial limitations, "the test applied by the courts is not the amount involved, but the nature of the transaction, whether the sale is in the regular course of the business of the corporation and in furtherance of the express objects of its existence, or something outside of the normal and regular course of the business." In the Matter of Miglietta, 287 N.Y. 246, 254-55, 39 N.E.2d 224, 228 (1942). For examples in other jurisdictions, see Thayer v. Valley Bank, 35 Ariz. 238, 276 Pac. 526 (1929); Jeppi v. Brockman Holding Co., 34 Cal. 2d 11, 206 P.2d 847 (1949) ; Warren v. Fitzgerald, 189 Md. 476, 56 A.2d 827 (1948) ; Van Buren v. Highway Ranch, Inc., 46 Wash. 2d 582, 283 P.2d 132 (1955). See also Note, 38 CALIF. L. Rev. 913, 916 (1950) ; cf. 46 CoLUM. L. Rev. 1020, 1022 n.6 (1946); 47 Mich. L. Rev. 411, 412 (1949).

8. "We do not think that section 20 of the [New York] Stock Corporation Law has any application to a contract for the sale of real estate of a corporation whose business is the sale of parcels of realty. ... [S]ection $20 \ldots$ has no application to the sale of commodities or articles which constitute the business of the corporation." Epstein v. Gosseen, 235 App. Div. 33, 36, 256 N.Y. Supp. 49, 52-53 (1st Dep't 1932). See also Keating v. Coleman, 214 App. Div. 668, 213 N.Y. Supp. 213 (2d Dep't 1925) ; Greenpoint Coal Docks, Inc. v. Newtown Creek Realty Corp., 5 Misc. 2d 812, 91 N.Y.S.2d 466 (Sup. Ct. 1949). But see Starrett Corp. v. Fifth Ave. \& Twenty-Ninth St. Corp., 1 F. Supp. 868, 874 (S.D. N.Y. 1932) (holding that a real estate corporation's sale of its sole asset requires statutory stockholder consent) ; Hodes v. 1299 Realty Corp., 278 App. Div. 803, 104 N.Y.S.2d 206 (1st Dep't 1951) ; Borea v. Locust Court Apartments, Inc., 234 App. Div. 450, 255 N.Y. Supp. 215 (2d Dep't 1932) (sale of lots by corporation primarily existing to own an apartment house within $\S 20$ ). For New York cases applying $\S 20$ to sale of integral assets other than realty, see In the Matter of Timmis, 200 N.Y. 177, 93 N.E. 522 (1910) (calendar department of a printing company); In the Matter of Kunin, 281 App. Div. 635, 121 N.Y.S.2d 220 (1st Dep't 1953), aff'd, 306 N.Y. 967, 120 N.E.2d 228 (1954) (banking business of a title and trust company). Section 20 has been held inapplicable to sales by a corporation formed for the express purpose of eventual liquidation. In the Matter of Miglietta, supra note 7, at 254-55, 39 N.E.2d at 228; Strauss v. Midtown Enterprises, Inc., 5 Misc. 2d 823, 825-26, 60 N.Y.S.2d 601, 604-05 (Sup. Ct. 1945); see In the Matter of Hurd, 5 Misc. 2d 443, 159 N.Y.S.2d 895 (Sup. Ct. 1957).

For cases in other jurisdictions exempting realty companies from stockholder consent statutes, see Thayer v. Valley Bank, supra note 7; Pollack v. Adwood Corp., 321 Mich. 93, 100, 32 N.W.2d 62, 65 (1948) ; Painter v. Brainard-Cedar Realty Co., 29 Ohio App. 123, 128-29, 163 N.E. 57, 58 (1928); Van Buren v. Highway Ranch, Inc., supra note 7.

9. Compare Wattley v. National Drug Stores Corp., 122 Misc. 533, 535, 204 N.Y. Supp. 254, 256 (Sup. Ct.), aff'd, 208 App. Div. 836, 204 N.Y. Supp. 956 (1st Dep't 1924) (dictum; in determining the statute's application, court need look no further than the specified powers contained in the corporate charter); In re United Gas Corp., 58 F. Supp. 501 (D. Del. 1944) (court relied on charter authorization to sell securities), with Kas- 
ness, does require stockholder approval, the further problem may arise of whether the method used to obtain consent was legally effective. ${ }^{10}$

The recent New York case of Eisen v. Post illustrates difficulties inherent in defining ordinary business activities and determining permissible consent procedure. ${ }^{11}$ Section twenty of the New York Stock Corporation Law requires that any sale of integral assets "not made in the regular course of business of the corporation" be approved in writing by all shareholders or in a meeting by holders of two thirds of the outstanding voting stock. ${ }^{12}$ Alleging noncompliance with section twenty, Eisen, owner of half the shares in Senior Estate, Ltd., brought a stockholder's derivative action to set aside the sale of the com-

zubowski v. Buffalo Tel. Corp., 131 Misc. 563, 227 N.Y. Supp. 435 (Sup. Ct. 1928) (ordinary course of business test not satisfied by fact charter authorized the sale); In the Matter of Kunin, supra note 8 (court went beyond charter and considered resultant changes in the nature of the corporate business). See also Note, 28 N.Y.U.L. REv. 1014, 1020 (1953).

10. Some courts have required strict compliance with the mode of approval prescribed by statute. See Starrett Corp. v. Fifth Ave. \& Twenty-Ninth St. Corp., 1 F. Supp. 868 (S.D. N.Y. 1932) (sale enjoined where notice of stockholders meeting held inadequate to constitute compliance with statute); In the Matter of Drosnes, 187 App. Div. 425, 175 N.Y. Supp. 628 (1st Dep't 1919) (dictum; sale voidable where stockholder consent obtained at a directors meeting instead of a stockholders meeting as provided in statute). Other courts have taken a functional view of the statutory requirements. See Texas Co. v. Z. \& M. Independent Oil Co., 156 F.2d 862, 866 (2d Cir. 1946) (granting specific performance of an option agreement: "If two-thirds of the stockholders individually consented it was as effective as if they had voted at a formal meeting") ; In re Robin Bros. Bakeries, Inc., 22 F. Supp. 662 (N.D. Ill. 1937) (actual approval, however informal, held sufficient under Illinois statute); cf. In re Victoria Fusilli Co., 79 F.2d 611 (2d Cir. 1935) (actual though not formal stockholder consent as specified in statute held sufficient authorization of mortgage) ; Black v. Ellis, 129 App. Div. 140, 113 N.Y. Supp. 558 (1st Dep't 1908), aff'd, 197 N.Y. 402, 90 N.E. 958 (1910) (same) ; Note, 51 HARv. L. Rev. 1074, 1080-82 (1938).

11. 3 N.Y.2d 518, 146 N.E.2d 779 (1957), reversing 1 App. Div. 2d 344, 149 N.Y.S.2d 864 (1st Dep't 1956).

12. N.Y. STOCK CoRp. LAw $\$ 20$ provides: "A stock corporation ... may voluntarily sell, lease or exchange its property, rights, privileges and franchises, or any interest therein or any part thereof; provided, however, that if such sale, lease or exchange is not made in the regular course of business of the corporation and involves all or substantially all of its property, rights, privileges and franchises, or an integral part thereof essential to the conduct of the business of the corporation, such sale, lease or exchange shall not be made without the consent of either the holders of record of all of its outstanding shares entitled to vote thereon given in writing without a meeting or the holders of record of two-thirds of its outstanding shares entitled to vote thereon obtained at a meeting of the stockholders called pursuant to section forty-five. ..."

"If the sale, lease or exchange may not be made without the consent of stockholders and such consent is obtained at a stockholders' meeting, any stockholder entitled to vote thereon and not voting in favor of such proposed sale, lease or exchange may at any time prior to the vote thereon ... object to such sale, lease or exchange and demand payment for his stock, and thereupon such stockholder or the corporation shall have the right, subject to the conditions and provisions of section twenty-one, to have such stock appraised and paid for as provided in said section. Such objection and demand must be in writing and filed with the corporation." 
pany's sole asset, a sublease of a theater. ${ }^{13} \mathrm{He}$ contended that the sale was not an ordinary business undertaking because in the past the corporation had only managed and operated the theater. ${ }^{14}$ Defendant purchaser argued that, since Senior's charter authorized transactions in real estate, the sale was in furtherance of express charter objectives and therefore within the statute's "regular course of business" exemption. ${ }^{15}$ Defendant claimed, alternatively, that Eisen's prior oral consent to the transfer estopped him from suing for rescission. ${ }^{10}$ The trial court denied plaintiff relief on both grounds, reasoning that section twenty is generally inapplicable to all realty transactions by a corporation chartered primarily to make them, and that Eisen's verbal agreement worked an estoppel. ${ }^{17}$ The appellate division reversed, holding that the statute applied to a real estate company disposing of its only asset, and that plaintiff's oral approval did not estop him since it was not given in writing or at a shareholders' meeting as required by the statute. ${ }^{18}$ Without reaching the estoppel issue, the court of appeals reversed the appellate division by classifying the transaction as one in the regular course of business and therefore not subject to section twenty. ${ }^{19}$ The court disregarded Senior's prior theatrical operations by terming them ultra vires and "holding ... that an ultra vires activity cannot be deemed the regular business of the corporation within the meaning of section 20."20 Instead, the court looked to the stated objectives of the charter and, finding among them sales such as the disputed one, concluded that dealing in real estate was the corporation's ordinary business. ${ }^{21}$

By invoking ultra vires to reject Senior's actual activities as the criterion for determining the company's regular course of business, the court misapplied an outmoded doctrine unsuited for deciding section twenty cases. Often criticized as inimical to business convenience and unfair to outsiders dealing with the corporation, $^{22}$ ultra vires has encountered disfavor in both legislatures and

13. The suit, to rescind an executed transfer of property, was primarily against the purchaser. The plaintiff also named as defendants the corporation's other two stockholders, who were also its officers. 3 N.Y.2d at 522, 146 N.E.2d at 780 .

The property was the Theater de Lys, site of the successful "The Threepenny Opera."

14. Id. at 524,146 N.E.2d at 781 .

15. Ibid.

16. 1 App. Div. $2 \mathrm{~d}$ at 346,149 N.Y.S.2d at 866 .

17. The trial court's opinion is not reported. See 3 N.Y.2d at 527, 146 N.E.2d at 783 (dissenting opinion) ; 1 App. Div, $2 d$ at 346,149 N.Y.S.2d at 866.

18. Id. at $346-47,149$ N.Y.S.2d at $866-67$.

19. 3 N.Y.2d at 524,146 N.E.2d at 781.

20. Id. at 525,146 N.E.2d at 782 . The court doubted that the corporation was actually engaged in operating the theater, but nevertheless based its decision on the assumption that the facts were as Eisen stated them.

21. Id. at 523-24, 146 N.E.2d at 781 .

22. Ballantine 266-67. The doctrine has also been criticized as based on erroneous premises. See Kahn-Freund, Company Law Reforms, 9 Modern L. Rev. 235, 236 (1946). To protect outsiders dealing with the corporation, the law of ultra vires has been abolished in California as between the corporation or its stockholders and third parties. CAL. CoRp. Code $\$ 803$; Ballantrne \& Sterling, California Corporation Laws 86 (1949). Ohio, 
courts, which have attempted to limit its force. Since acts are ultra vires only when exceeding the powers granted the corporation by statute or charter, ${ }^{23}$ widespread legislation allowing broad multipurpose or "all purpose" charter provisions has effectively reduced the doctrine's utility. ${ }^{24}$ In addition, most courts, reluctant to designate corporate activity ultra vires, ${ }^{25}$ frequently characterize transactions as incidental to the achievement of authorized corporate goals. ${ }^{20}$ Thus, had it followed the weight of decisional law, the Eisen court would probably have considered Senior's managerial operations legitimate corporate functions. The questioned activities-approving plays, purchasing equipment and appointing business agents-were all intended to ensure a continuing profitable return on subleases to theatrical producers; and the charter empowered the company "to operate, let and sublet buildings ... and to perform any and all further acts ... which may in anywise contribute to the enhancement of its business . ..."27 Furthermore, even if the Senior charter did not permit the operation of a theater, ultra vires was inapposite. That doctrine's sole function is to protect shareholders against unsanctioned corporate undertakings. ${ }^{28}$ Here, all the stockholders had consented to and participated in Senior's theatrical ventures. ${ }^{29}$ Consequently, resort to ultra vires language in order to

Minnesota and Michigan have limited the doctrine's availability against third parties to cases in which the outsider had actual knowledge that the transaction exceeded corporate authority. Ibid. However, such limitations do not immunize asset sales made in violation of state statutes. $I d$. at 87 .

23. Stevens, Corporations 292-93 (2d ed. 1949); see 2 Machen, Corporatrons $\$ 1012$ (1908).

24. For a typical multipurpose statute, see DeL. Code ANn. tit. 8, \$§ 101-02, 121-22 (Supp. 1956). For a general discussion, see Dodd \& BAkER, Corporations 344-45 (2d ed. 1951).

An "all purpose" statute permits the corporation to perform any activity allowed a natural person. See Nev. Rev. Stat. \$ 78.035(3) (1957); WIS. Stat. ANN. § 180.45 (1) (c) (1955) ; see also Luce, Trends in Modern Corporation Legislation, 50 MICH. L. REv. 1291, 1301 (1952).

25. See, c.g., Benson Lumber Co. v. Thornton, 185 Minn. 230, 237, 240 N.W. 651, 654 (1932) ; Jacobs v. Monaton Realty Inv. Corp., 212 N.Y. 48, 56, 105 N.E. 968, 970-71; The Rider Life Raft Co. v. Roach, 97 N.Y. 378 (1884) ; 6 FletcheR, op. cit. supra note 2, at $\S \S 2505,2586$.

26. See, e.g., Jacksonville, M., P. Ry. \& Nav. Co. v. Hooper, 160 U.S. 514 (1896) (railroad corporation allowed to operate hotel) ; Fogelson v. Rackfay Constr. Co., 1.95 Misc. 550, 91 N.Y.S.2d 910 (Sup. Ct.), aff'd, 276 App. Div. 752, 92 N.Y.S.2d 608 (1st Dep't 1949), rev'd on other grounds, 300 N.Y. 334, 90 N.E.2d 881 (1950) (real estate corporation allowed to operate bus service for tenants). Cf. Stevens, Corporations 235 (2d ed. 1949).

27. 3 N.Y.2d at 523,146 N.E.2d at 781 .

28. Ballantine 241-42. Creditors are protected through the doctrines of fraudulent conveyance and illegal capital impairment. $I d$. at 258-60, 676-80. See also Note, 38 CALIF. L. REv. 913, 919-20 (1950).

29. See 3 N.Y.2d at 526-27, 146 N.E.2d at 783 (dissenting opinion). Furthermore, absent either creditors' rights or a breach of public policy, unanimous stockholder consent generally validates any corporate activity. See Elyea v. Lehigh Salt Mining Co., 169 N.Y. 29, 61. N.E. 992 (1901) ; Martin v. The Niagara Falls Paper Mfg. Co., 122 N.Y. 165, 172, 25 N.E. 303, 305 (1890). See also Ballantine § 101. 
deprive a shareholder of the protection conferred by section twenty seems singularly inappropriate.

Divergent views obtain on the weight attributable to charter provisions when deciding the applicability of stockholder-consent statutes. Some courts examine a corporation's day-by-day activities to determine whether a sale of assets falls within its regular course of business; others look primarily to its charter. ${ }^{3 n}$ The Eisen court adopted the latter approach by disregarding what Senior actually did and relying entirely on the previously unexercised but charterauthorized power to deal in real estate. ${ }^{31}$ Such formalism misconstrues a statute intended to protect basic shareholder expectations. Since stock purchases are invariably made on the basis of activities a corporation in fact pursues, safeguarding the essential nature of stockholder investments requires that consent provisions apply whenever a proposed sale of property would significantly alter normal corporate business. ${ }^{32}$ Using charter provisions as exclusive criteria for ascertaining such a change is unrealistic. The prevalence of multipurpose provisions ${ }^{33}$ renders the charter an inaccurate reflection of a company's real business. ${ }^{34}$ Moreover, a corporation, by listing trading in capital assets as one of its purposes, might easily avoid the requirements of section twenty. ${ }^{35}$ To effectuate the statute's aims, therefore, courts should look beyond a corporation's charter to its method of operation and past history in order accurately to define its regular course of business. ${ }^{36}$

30. See note 9 supra.

31. 3 N.Y.2d at $525-26,146$ N.E.2d at 782. Although the majority prudently disclaimed the idea "that the certificate of incorporation determines the business a corporation is in fact doing," id. at 525, 146 N.E.2d at 782, the dissent was clearly right in characterizing the decision as a holding "that the corporation's regular course of business must be determined solely by an examination of the words found in the certificate, without considering the activity upon which the company is actually engaged." Id. at 527,146 N.E.2d at 783 .

32. See id. at 528-29, 146 N.E.2d at 784 (dissenting opinion) ; In the Matter of Kunin, 281 App. Div. 635, 121 N.Y.S.2d 220 (1st Dep't 1953), aff'd, 306 N.Y. 967, 120 N.E.2d 228 (1954) (in determining whether a transaction is in the regular course of a corporation's business, court considered the resultant changes in the nature of the actual corporate business).

33. See note 24 supra.

34: "It has arrived now at a point at which the fact is that the function of the [charter] . . . is . . . not to specify, not to disclose, but to bury beneath a mass of words the real object or objects of the company with the intent that every conceivable form of activity shall be found included somewhere within its terms." Cotman v. Brougham, [1918] A.C. 514, 523. See also Louis Grunow Memorial Clinic v. Davis, 49 Ariz. 277, 287, 66 P.2d 238, 242-43 (1937) ; Ballantine 221.

35. Even without such a listing, N.Y. STOCK CoRP. LAw $\S 51$ on its face permits a corporation to eliminate stockholder voting rights on asset sales by specific provision in its certificate of incorporation. But see Ballantine \& Sterling, California Corporation LAws 397 (1949) (the necessity of stockholder approval in California may not be eliminated by charter provision).

36. See Schreiber v. Butte Copper \& Zinc Co., 98 F. Supp. 106, 111 (S.D.N.Y. 1951). 
To protect the good faith purchaser, a liberal employment of estoppel doctrine should accompany factual determination of transactions activating stockholder-consent provisions. The necessity of examining a corporation's actual business in addition to its charter would place an extra burden on the purchaser assessing the relevance of section twenty to his particular transaction. ${ }^{37}$ His risk could be reduced by estopping shareholders from suing for rescission or injunction if they had in reality previously consented to the asset transfer. ${ }^{38}$ Section twenty specifies two possible modes of shareholder approval-unanimous consent in writing or a favorable vote of two thirds of the shares at a duly convened stockholders' meeting. ${ }^{39}$ In Eisen, the appellate division refused to bar plaintiff's suit because his prior assent was not given at a formal meeting and was only oral. ${ }^{40}$ The grounds for equitable estoppel, however, should not simply be failure to comply with statutory consent procedures. Rather, equitable principles may properly be used here to achieve legislative purpose irrespective of compliance with technical requirements. ${ }^{41}$ The basic objective of the writing and meeting provisions is to provide formal evidence of a share-

37. See 3 N.Y.2d at 530,146 N.E.2d at 785 (dissenting opinion). Of course, the prudent purchaser would always require $\$ 20$ authorization in statutory form. But in the close corporation context, prudence may be subordinated to convenience if not ignorance. See Gerard v. Empire Square Realty Co., 195 App. Div. 244, 187 N.Y. Supp. 306 (2d Dep't 1921); 1 \& 2 O'Neal, Close Corporations $\$ \S 1.12,8.03$ at $\$ 6$ (1958).

38. In the absence of fraud or mistake, courts generally hold that an asset sale cannot be attacked by the corporation or stockholders who have assented thereto. See Autauga Co-Operative Leasing Ass'n v. Ward, 250 Ala. 229, 233-34, 33 So. 2d 904, 907 (1948); In the Matter of Drosnes, 187 App. Div. 425, 430, 175 N.Y. Supp. 628, 632 (1st Dep't 1919) ; Wentworth v. Braun, 78 App. Div. 634, 79 N.Y. Supp. 489 (1st Dep't), aff'd, 175 N.Y. 515, 67 N.E. 1091 (1903); Akin v. Bates, 89 Ore. 260, 173 Pac. 889 (1918); 6A Fletcher, Private Corporations 684 n.94 (perm. ed. rev. repl. 1950). See also People v. Ballard, 134 N.Y. 269, 295, 32 N.E. 54, 59 (1892); Kent v. Quicksilver Mining Co., 78 N.Y. $159,185-86$ (1879).

39. See note 12 supra.

40. See note 18 stipra.

41. Based on equity, estoppel in pais may be applied where justice requires preventing a party from asserting his rights under technical rules of law. Basak v. Damutz, 105 Conn. 378, 135 Atl. 453 (1926) (irrespective of legal rights, estoppel is based on equity and good conscience); Lieberman v. Templar Motor Co., 236 N.Y. 139, 140 N.E. 222 (1923) (assent to new terms of a contract required by law to be in writing, even if invalid as a contract, will serve as an estoppel) ; cf. Hill v. National Bank, 97 U.S. 450 (1878). See 31 C.J.S., Estoppel $\$$ 62, at 248 n.83 (1942) (collecting cases). Estoppel holds a person to his prior representations on which others have in good faith relied. Arizona ex rel. Gaines v. Capper Queen Consol. Mining Co., 233 U.S. 87, 95 (1914). See 19 AMr. Jur, Estoppel $\$ 42$, at 641 n.18 (1939) (collecting cases). In the corporate field, stockholders have been estopped from contesting transactions to which they had previously consented even though such consent was not in the required legal form. In Autauga Co-Operative Leasing Ass'n v. Ward, 250 Ala. 229, 33 So. 2 d 904 (1948), the statute required that four fifths of the shareholders ratify the directors' decision to sell at a meeting called for that purpose. Unanimous shareholder approval was obtained, but not through the procedure specified by statute. Neither had the board of directors previously voted for the sale nor had the shareholders meeting been properly called. The court held that the statutory purpose-to pro- 
holder's vote-an evidentiary function which can be satisfied through less formal means. ${ }^{42}$ Nevertheless, a shareholder who had consented informally could argue that, with the benefit of discussion incident to a meeting, he might not have given his approval. ${ }^{43}$ This provision lacks force in the usual section twenty context of a close corporation, ${ }^{44}$ since the views of other shareholders are normally readily accessible. ${ }^{45}$ In a widely held corporation, providing stockholders with complete information concerning a proposed sale may serve as a realistic substitute for a general meeting which most of them are unlikely to attend. ${ }^{46}$ Moreover, omission of the meeting requirement from section twenty in cases of unanimous stockholder approval indicates legislative recognition of the inutility of a meeting as a meaningful forum for decision-making in certain situations. ${ }^{47}$ Thus, whenever a shareholder has received the full benefits intended by the statute, equity should not allow him to repudiate prior consent at the expense of the good-faith purchaser.

While the use of estoppel can protect the purchaser against the claim of a reneging assenter, the remedies of a genuine dissenter from an informally approved sale require clarification. When a corporation fails to obtain requisite stockholder consent, a disapproving shareholder can bring a representative action to rescind or enjoin a transfer of assets; $;^{48}$ and, absent a breach of

tect the shareholders-was fulfilled by unanimous shareholder consent obtained by nonstatutory means. Accordingly, the purchasers' suit for specific performance was granted.

See also Akin v. Bates, 89 Ore. 260, 173 Pac. 889 (1918) (stockholder who participated in transfer of corporate property estopped from impeaching the regularity of the proceedings); BALLANTINE $\$ 170$.

42. The minutes of corporate meetings often contain a record of stockholder votes. See $i d$. at 391. Although some states have eliminated stockholder meeting requirements generally, they have retained their evidentiary function by requiring that individual shareholder action be in writing. Id. at $391 \mathrm{n} .58$ (collecting statutes).

43. See 19 Fletcher, Private Corporations $\$ 9017$ (rev. perm. ed. 1933) ; BallanTINE $390 ; c f . i d$. at 124 (value of discussion and interchange of views at directors meetings).

44. Ignorance of, or lax compliance with, statutory dictates is more likely in the conduct of close corporations than publicly held ones. Gerard v. Empire Square Realty Co., 195 App. Div. 244, 187 N.Y. Supp. 306 (2d Dep't 1921).

45. Recognizing this accessibility, courts in such contexts have often been tolerant of failure rigidly to comply with statutory meeting requirements. See Gerard v. Empire Square Realty Co., supra note 44; cf. Dodd \& Baker, Corporations 159 n.2 (2d ed. 1951) (where directors generally act informally, many states do not require a meeting).

46. Meetings are relatively unimportant in large corporations and shareholder control is exercised primarily through proxies. See Emerson \& Latchazr, Shareholder DenrocRACY 13 (1954). Therefore, shareholder protection is best insured by requiring that a full disclosure of issues and facts concerning the sale of integral assets accompany proxy solicitations.

47. Section 20 , as amended in 1954 , permits unanimous approval in writing as an alternative to consent obtained at a stockholders meeting. See note 12 supra.

48. See, e.g., Westerlund v. Black Bear Mining Co., 203 Fed. 599 (Sth Cir. 1913) (rescission) ; Starrett Corp. v. Fifth Ave. \& Twenty-Ninth St. Corp., 1 F. Supp. 868 (S.D.N.Y. 1932) (injunction); Kaszubowski v. Buffalo Tel. Corp., 131 Misc. 563, 227 N.Y. Supp. 435 (Sup. Ct. 1928) (rescission). See Schreiber v. Butte Copper \& Zinc Co., 98 F. Supp. 106, 112 (S.D.N.Y. 1951) (dictum) ; Notes, 38 CaLIF. L. REv. 913, 920 (1950), 28 N.Y. 
fiduciary relationship, ${ }^{40}$ agreement in statutory form makes appraisal the dissenter's exclusive remedy. ${ }^{50}$ When the method of expressing consent deviates from the statutory norm, however, available relief is uncertain. ${ }^{51}$ Taking a mandatory view of section twenty procedure, some courts indicate that stockholder concurrence at an irregularly convened meeting would not bar a dissenter from suing for rescission or injunction. ${ }^{52}$ Other courts suggest that a two thirds vote of approval obtained by any procedure would limit a dissenter to appraisal. ${ }^{53}$ With modification, the latter approach seems preferable. If the

U.L. KEv. 1014, 1018-19 (1953). But see In the Matter of Drosnes, 187 App. Div. 425, 175 N.Y. Supp. 628 (1st Dep't 1919). In this case, although the requisite two-thirds consent had not been obtained, the complaining shareholder was still permitted to demand an appraisal in lieu of attempting to rescind.

This approach may be supported by an equity court's general power to grant nonstatutory appraisal when rescission would be inequitable. Jones v. Missouri-Edison Elec. Co., 144 Fed. 765 (Sth Cir. 1906) (on demurrer), upheld, 199 Fed. 64 (8th Cir. 1912), cort. denied, 229 U.S. 615 (1913). However, it might work a partial dissolution of the corporation if a large number of the shareholders demanded the appraisal. Thus, a substantial number of shareholders could cause an effective dissolution even though the state corporation law required a two-thirds vote for such action.

49. Even when statutory consent is obtained, dissenting shareholders may have equitable relief if the transaction is fraudulent, e.g., Weckler v. Valley City Mill Co., 93 F. Supp. 444 (W.D. Mich. 1950), aff'd, 18s F.2d 367 (6th Cir. 1951) ; Kavanaugh v. Kavanaugh Knitting Co., 226 N.Y. 185, 123. N.E. 148 (1919), if the majority stockholders or directors have disregarded the minority's interest, e.g., Lebold v. Inland Steel Co., 125 F.2d 369 (7th Cir. 1941), cert. denied, 316 U.S. 675 (1942), modified, 136 F.2d 876 (7th Cir. 1943); Allied Chemical \& Dye Corp. v. Steel \& Tube Co., 14 Del. Ch. 1, 120 Atl. 486 (1923), if the directors have acted negligently, e.g., Bown v. Ramsdell, 227 App. Div. 224, 237 N.Y. Supp. 573 (4th Dep't 1929), or if the majority has designed the transaction to deprive minority shareholders of a vote, e.g., Eisenberg v. Central Zone Property Corp., 306 N.X. 58, 115 N.E.2d 652 (1953). See Note, 58 Colun. L. Rev. 251, 255 (1958) (the rule that appraisal is the exclusive remedy seems limited to situations in which the sale is in good faith).

50. Some statutes make appraisal the exclusive remedy. Mich. Stat. Ann. $\S 21.44$ (Supp. 1957) ; PA. Stat. ANn. tit. 15, $\$ 2852-810$ (Supp. 1957). In jurisdictions where the statutes are silent on the exclusiveness of the appraisal remedy, courts have generally reached the same conclusion. E.g., Blumenthal v. Roosevelt Hotel, Inc., 202 Misc. 988, 115 N.Y.S.2d 52 (Sup. Ct. 1952) ; see Beloff v. Consolidated Edison Co., 300 N.Y. 11, 19-20, 87 N.E.2d 561, 564-65 (1949). For decisions in other states, see Geiger v. American Seeding Mach. Co., 124 Ohio St. 222, 177 N.E. 594 (1931); Wick v. Youngstown Sheet \& Tube Co., 46 Ohio App. 253, 267-68, 188 N.E. 514, 519-20 (1932) ; cf. Opelka v. Quincy Memorial Bridge Co., 335 Ill. App. 402, 410-11, 82 N.E.2d 184, 188 (1948) ; Johnson v. Spartanburg County Fair Ass'n, 210 S.C. 56, 70, 41 S.E.2d 599, 605 (1947). But see Cole v. Wells, 224 Mass. 504, 113 N.E. 189 (1916) ; Craddock-Terry Co. v. Powell, 181 Va. 417, 25 S.E.2d 363 (1943). See Lattin, Remedies of Dissenting Stockholders Under A praisal Statutes, 45 HARv. L. Rev. 233, 244, 258 (1931) ; Note, 58 Colum. L. Rev. 251, 254 (1958).

51. See note 10 supra.

52. See Starrett Corp. v. Fifth Ave. \& Twenty-Ninth St. Corp., 1 F. Supp. 868 (S.D. N.Y. 1932) ; In the Matter of Drosnes, 187 App. Div. 425, 175 N.Y. Supp. 628 (1st Dep't 1919), discussed note 10 supra.

53. See Texas Co. v. Z. \& M. Independent Oil Co., 156 F.2d 862, 866 (2d Cir. 1946) ; 
complaining shareholder had notice and an opportunity to dissuade supporters of the sale, the absence or irregularity of the statutorily prescribed meeting is irrelevant since its discussionary function is satisfied. ${ }^{54}$ Although the reasoning of some courts implies acceptance of such a functional test, ${ }^{55}$ it can only be applied in derogation of the statute's explicit language. ${ }^{56}$ By making the designated consent procedure permissive only, a statutory amendment would allow courts to subordinate form to function in adjusting purchaser and dissenting shareholder interests. ${ }^{57}$

Estoppel doctrine and the suggested functional consent test, while affording substantial protection to the purchaser, would leave rescission or injunction available if basic statutory objectives were violated. Thus, if a dissenting shareholder had no knowledge of the sale or two thirds of the stockholders did not in fact approve it, the purchaser's interest in transferred property would be defeasible. ${ }^{58}$ This result would not unduly impair title certainty ${ }^{59}$ since an unauthorized asset sale is generally considered voidable rather than void, ${ }^{60}$ and courts on grounds of laches and equitable estoppel bar claims by dissenters who fail to pursue their remedies promptly. ${ }^{61}$ Consequently, an enlightened

In re Robin Bros. Bakeries, Inc., 22 F. Supp. 662 (N.D. Ill. 1937) ; see also In re Victoria Fusilli Co., 79 F.2d 611 (2d Cir. 1935).

54. See text at note 43 supra.

55. See cases cited note 53 supra.

56. The statute provides that asset sales "shall not be made" absent compliance with the statutory mode of consent. See note 12 supra.

57. Such an amendment would permit courts to grant appraisal when sufficient informal consent is obtained and would overrule prior cases reasoning that appraisal is available only if the corporation and the stockholder had strictly complied with statutory procedure. See Starrett Corp. v. Fifth Ave. \& Twenty-Ninth St. Corp., 1 F. Supp. 868, S78 (S.D. N.Y. 1932) (only by procedures in strict accordance with $\$ 20$ and $\$ 49$ can a dissenting shareholder get appraisal) ; Cochules v. 116 East 57th Street, Inc., 125 N.Y.S.2d 97, 99 (Sup. Ct. 1953) (compliance with $\S 20$ is condition precedent to appraisal). See also Johnson v. Brigham Co., 126 Me. 108, 136 At1. 456 (1927) (stockholder who failed to vote at a meeting not entitled to appraisal notwithstanding fact his vote would have been useless).

58. See note 48 supra and accompanying text.

59. The argument that title certainty would be unduly impaired was raised in the Brief for the New York State Title Association as Amicus Curiae, p. 17, Eisen v. Post, 3 N.Y. 2d 518, 146 N.E.2d 779 (1957).

60. Sheldon Hat Blocking Co. v. Eickemeyer Hat Blocking Mach. Co., 90 N.Y. 607 (1882) ; In the Matter of Drosnes, 187 App. Div. 425, 175 N.Y. Supp. 628 (1st Dep't 1919) ; Schneider v. Greater M. \& S. Circuit, Inc., 144 Misc. 534, 259 N.Y. Supp. 319 (Sup. Ct. 1932) ; Ballantine \& Sterling, California Corporation Laws 398-99 (1949); see Schreiber v. Butte Copper \& Zinc Co., 98 F. Supp. 106, 111 (S.D.N.Y. 1951). But see Eisen v. Post, 1 App. Div. 2d 344, 149 N.Y.S.2d 864 (1st Dep't 1956), rev'd, 3 N.Y.2d 518, 146 N.E.2d 779 (1957) (sale in violation of statute is void) ; In the Matter of Macdonald, 205 App. Div. 579, 199 N.Y. Supp. 873 (2d Dep't 1923) (same in dictum; whether void or voidable not pertinent to outcome of case).

61. See Cole v. Birmingham Ry., 143 Ala. 427, 39 So. 403 (1904); Sheldon Hat Blocking Co. v. Eickemeyer Hat Blocking Mach. Co., supra note 60; Schneider v. Greater M. \& S. Circuit, Inc., supra note 60; Narragansett Elec. Lighting Co. v. Sabre, 51 R.I. 
application of available doctrine could effectuate the policy of stockholder consent statutes with minimal disruption of executed corporate transactions.

37, 150 At1. 756 (1930) ; Ballantine 675; Ballantine \& Sterling, op. cit. supra note 60, at 398-99. See also Note, 38 Calif. L. Rev. 913, 920 (1950) ; Annot., 70 A.L.R. 53 (1931) (collecting cases).

The appellate division in Eisen considered the sale void. If this view were accepted, laches would be inapplicable since defendant purchaser, receiving no better title than that of his transferor, would only have anly a void title; his sole possible claim to the property would be on adverse possession. But the appellate division's view is against the decided weight of authority. See note 60 stpra. Since the appellate division's position was not considered by the court of appeals, it cannot be taken as the law of the state. 